\title{
Effects of purinergic agonists on aromatase and gamma- glutamyl transpeptidase activities and on transferrin secretion in cultured Sertoli cells
}

\author{
S B Meroni, D F Cánepa, E H Pellizzari, H F Schteingart \\ and $\mathbf{S}$ B Cigorraga \\ Centro de Investigaciones Endocrinológicas, Hospital de Niños R Gutiérrez, Buenos Aires, Argentina \\ (Requests for offprints should be addressed to S B Cigorraga, Centro de Investigaciones Endocrinológicas, Hospital de Niños R Gutiérrez, \\ Gallo 1330-(1425) Buenos Aires, Argentina)
}

\begin{abstract}
To study the role of extracellular nucleosides and nucleotides in the regulation of Sertoli cells, the effects of agonists which occupy $\mathrm{A}_{1}$ and $\mathrm{P}_{2}$ purinergic receptors on aromatase and gamma-glutamyl transpeptidase $(\gamma-\mathrm{GTP})$ activities and on transferrin secretion were tested. Sertoli cell treatment with purinergic agonists for a prolonged period of time $(72 \mathrm{~h})$ resulted in an increase in aromatase activity under basal conditions. In cultures stimulated with FSH, purinergic agonists counteracted the inhibitory effect on aromatase activity that long-term treatment with FSH promoted. The effects of prolonged treatments with purinergic agonists on the other two parameters of Sertoli cell function were less pronounced. Neither $\gamma$-GTP activity nor transferrin secretion was modified under basal
\end{abstract}

conditions. On the other hand, under conditions where cell differentiation was favored by FSH treatment, reductions in $\gamma$-GTP activity and transferrin secretion were usually observed. The results obtained in dbcAMPstimulated cultures suggested that $A_{1}$ agonists exert their regulatory function at the level of cAMP formation while $\mathrm{P}_{2}$ agonists act at a more distal point. The fact that morphological changes induced by FSH were reversed by both types of agonists, while those induced by dbcAMP were only abrogated by $\mathrm{P}_{2}$ agonists, supports this hypothesis. In summary, these results demonstrate that purinergic agonists may be important in the regulation of Sertoli cell function.

Journal of Endocrinology (1998) 157, 275-283

\section{Introduction}

The role of nucleosides and nucleotides in metabolism is well established but their potential importance as extracellular chemical messengers has been recognized only recently (Burnstock 1990). They are now known to participate in a variety of biological responses (Fradkin et al. 1982, Martin et al. 1985, Shima 1986, Hopwood \& Burnstock 1987, Billig \& Rosberg 1988, LoubatieresMariani \& Chapal 1988). These responses are mediated by specific surface purinergic receptors: $\mathrm{P}_{1}$ receptors, which have high affinity for extracellular adenosine and AMP, and $\mathrm{P}_{2}$ receptors with high affinity for ADP and ATP (Paton \& Taerum 1990).

$\mathrm{P}_{1}$ receptors have been subclassified into $A_{1}, A_{2 A}, A_{2 B}$ and $A_{3}$ receptors on the basis of differing agonist affinity and on the different effects on adenylate cyclase (Londos \& Wolff 1977, Stehle et al. 1992, Carruthers \& Fozard 1993). Subclassification of $\mathrm{P}_{2}$ receptors includes five different subtypes at the moment and the biochemical signals they elicit are more variable (Dubyak 1991, Barnard et al. 1994).
In Sertoli cells, Monaco et al. (1988) have studied the biochemical properties of the $\mathrm{P}_{1}$ purinergic receptors and the biological effects of adenosine. Those authors have shown that $P_{1}$ receptors present in these cells belong to $A_{1}$ subtype. In agreement with what has been shown for other tissues, they are coupled to a $G_{i}$ protein and their occupancy leads to inhibition of adenylate cyclase. In accordance with this inhibition, several parameters of Sertoli cell function - follicle-stimulating hormone (FSH)dependent secretion of pyruvate (Conti et al. 1989), FSH stimulation of aromatase activity (Monaco et al. 1984) and FSH stimulation of inhibin secretion (Conti et al. 1988) are negatively modulated by adenosine receptor agonists.

Histochemical studies showed that $A_{1}$ receptors are concentrated at the interface between Sertoli and germinal cells (Monaco \& Conti 1986). It has been suggested that adenosine receptors on Sertoli cells are part of a paracrine system in which adenosine can be released when changes in the metabolic status in germinal cells occur (Conti et al. 1989).

As for $\mathrm{P}_{2}$ receptors a recent study has shown that Sertoli cells possess the $\mathrm{P}_{2 \mathrm{U}}$ subtype which is associated with 
phosphatidylinositol turnover and intracellular $\mathrm{Ca}^{2+}$ mobilization. Occupancy of these receptors causes inhibition of the FSH-dependent increase in intracellular cAMP and of the CAMP-mediated cell shape changes (Filippini et al. 1994). A more recent report (Foresta et al. 1995) showed that ATP action is also coupled to selective $\mathrm{Na}^{+}$ influx and the authors postulated that membrane depolarization causes opening of voltage-gated $\mathrm{Ca}^{2+}$ channels that contribute to the sustained $\mathrm{Ca}^{2+}$ response. As yet, the physiological role of $\mathrm{P}_{2}$ purinergic receptors in the regulation of Sertoli cell function remains to be clearly determined.

In the present study we have investigated whether prolonged treatment of Sertoli cell cultures with purinergic agonists regulates aromatase and gammaglutamyl transpeptidase ( $\gamma$-GTP) activities and transferrin secretion under basal and FSH-stimulated conditions.

\section{Materials and Methods}

\section{Materials}

Ovine FSH (NIH-oFSH-S-16) was obtained from the National Hormone and Pituitary Program, NIDDK (National Institute of Diabetes, Digestive and Kidney Diseases, Bethesda, MD, USA). Tissue culture media were purchased from Grand Island Biological Co. (Grand Island, NY, USA). All other drugs and reagents were purchased from Sigma Chemical Co. (St Louis, MO, USA).

\section{Sertoli cell isolation and culture}

Sertoli cells from 20-day-old Sprague-Dawley rats were isolated as previously described (Schteingart et al. 1989). Briefly, decapsulated testes were digested with $0 \cdot 1 \%$ collagenase and $0.06 \%$ soybean trypsin inhibitor in Hanks' balanced salt solution for $5 \mathrm{~min}$ at room temperature. Seminiferous tubules were saved, cut and submitted to $1 \mathrm{M}$ glycine-2 mM EDTA ( $\mathrm{pH} 7 \cdot 4$ ) treatment to remove peritubular cells. The washed tubular pellet was then digested again with collagenase for $10 \mathrm{~min}$ at room temperature to remove germinal cells. The Sertoli cell suspension, collected by sedimentation, was resuspended in culture medium which consisted of a 1:1 mixture of Ham's F-12 and Dulbecco's modified Eagle's medium, supplemented with $20 \mathrm{mM}$ Hepes, $100 \mathrm{IU} / \mathrm{ml}$ penicillin, $2.5 \mu \mathrm{g} / \mathrm{ml}$ amphotericin $\mathrm{B}, 1.2 \mathrm{mg} / \mathrm{ml}$ sodium bicarbonate, $10 \mu \mathrm{g} / \mathrm{ml}$ transferrin, $5 \mu \mathrm{g} / \mathrm{ml}$ insulin, $5 \mu \mathrm{g} / \mathrm{ml}$ vitamin $\mathrm{E}$ and $4 \mathrm{ng} / \mathrm{ml}$ hydrocortisone. Sertoli cells were cultured in 24 -well plates $\left(10 \mu \mathrm{g}\right.$ DNA/well) at $34^{\circ} \mathrm{C}$ in a mixture of $5 \% \mathrm{CO}_{2}: 95 \%$ air. Cells were allowed to attach for $48 \mathrm{~h}$. Treatments started on day 3 and were performed in culture medium without the addition of insulin.
Purity of Sertoli cells reached $95 \%$ after 5 days in culture as seen by phase contrast microscopy (see Fig. 5A). No myoid cell contamination was revealed when an immunoperoxidase technique was applied to Sertoli cell cultures using a specific antiserum to alpha-smooth muscle actin. Remaining cell contaminants were of germ cell origin.

\section{Culture conditions}

$(-) \mathrm{N}^{6}$-(R-phenylisopropyl)-adenosine (PIA, $100 \mathrm{nM}$ ) and $\mathrm{N}^{6}$-cyclohexyl-adenosine (CHA, $100 \mathrm{nM}$ ) were used as agonists for $A_{1}$ receptors. ADP $(100 \mu \mathrm{M})$ and ATP $(100 \mu \mathrm{M})$ were used to elicit responses through $\mathrm{P}_{2}$ receptors. Concentrations of purinergic agonists were chosen in accordance with the literature (Monaco et al. 1988, Filippini et al. 1994) and also with our personal data (Tables 1 and 3).

For short-term treatment, cells were maintained under basal conditions until the 6th day, when purinergic agonists were added with the aromatization mixture. Twenty-four hours later, media were collected and saved for estradiol determinations.

For long-term treatment, to evaluate the effects of purinergic agonists on $\gamma$-GTP activity and on transferrin secretion, purinergic agonists were added every day for 4 days beginning on day 3. FSH or dbcAMP stimulation was performed on day 3 and on day 6 when medium was changed. $\gamma$-GTP activity was determined on the cells harvested on day 7 . The 72-h conditioned media obtained on day 6 were used to evaluate transferrin levels. In parallel cultures, cells which had received three pulses of purinergic agonists (days 3, 4 and 5) were washed and aromatase activity was evaluated in the absence of purinergic agonists.

Cell viability at the end of the culture period was evaluated by a Trypan Blue exclusion test. Under all experimental conditions tested cell viability was higher than $95 \%$.

\section{Aromatase assay}

To evaluate aromatase activity, $100 \mathrm{ng} / \mathrm{ml} \mathrm{FSH}$ and $3 \mu \mathrm{M}$ testosterone as substrate for aromatization were added on the 6th day with the medium change. Media were collected $24 \mathrm{~h}$ later (day 7), centrifuged at $1100 \mathrm{~g}$ for 10 min and stored at $-20{ }^{\circ} \mathrm{C}$ until estradiol determinations were performed. The monolayers were washed with $0.9 \% \mathrm{NaCl}$ solution and $0.5 \mathrm{ml} 2 \mathrm{mM}$ EDTA (pH 7.4) was added. Cells were disrupted by ultrasonic irradiation and adequate aliquots for DNA determinations were saved.

\section{$\gamma$-Glutamyl transpeptidase assay}

$\gamma$-GTP activity was assayed by the method of Orlowsky \& Meister (1963) using L- $\gamma$-glutamyl p-nitroanilide as 
substrate and glycylglycine as the acceptor molecule. Sertoli cell monolayers were disrupted by ultrasonic irradiation in $0.5 \mathrm{ml}$ reaction buffer $(0.1 \mathrm{M}$ Tris buffer, 0.01 $\mathrm{M} \mathrm{MgCl}_{2}, 0 \cdot 02 \mathrm{M}$ glycylglycine, $\left.\mathrm{pH} 9 \cdot 0\right)$. Adequate aliquots for DNA determinations were saved and $5 \mathrm{mM}$ substrate (L- $\gamma$-glutamyl p-nitroanilide) was added to the remaining material. The reaction was allowed to proceed for $120 \mathrm{~min}$ at $34^{\circ} \mathrm{C}$, and the enzymatic reaction was stopped by addition of acetic acid to $1 \mathrm{M}$ concentration. Samples were then centrifuged and absorbances determined in a spectrophotometer at $410 \mathrm{~nm}$. Values were compared against a standard curve with increasing concentrations of $\mathrm{p}$-nitroaniline.

\section{Transferrin determination}

Rat transferrin was measured by RIA as described by Handelsman et al. (1989). A polyclonal antibody raised against rat transferrin in rabbits was used (Cappel Laboratories, Cochranville, PA, USA). The crossreactivity of human transferrin in this assay is less than $0.003 \%$. Unconditioned medium containing $10 \mu \mathrm{g} / \mathrm{ml}$ human transferrin did not show any cross-reactivity in this assay. This RIA has a sensitivity of $3 \mathrm{ng} /$ tube and intraand interassay coefficients of variation of 7 and $16 \%$ respectively.

\section{Other assays}

DNA was determined by the method of Labarca \& Paigen (1980). RIA of estradiol was performed according to the method of Escobar et al. (1976), using a specific antibody which cross-reacts less than $1 \%$ with estrone and estriol. This RIA has a sensitivity of $6.25 \mathrm{pg} / \mathrm{tube}$ and intra- and interassay coefficients of variation of 8 and $15 \%$ respectively.

\section{Statistical analysis}

Statistical analysis was performed by ANOVA followed by Tukey's protected $t$-test for comparison of data from multiple groups using the GB-STAT version $4 \cdot 0$ statistical program (Dynamic Microsystems, Inc., Silver Spring, MD, USA).

\section{Results}

Effect of purinergic agonists on FSH- and dbcAMP-stimulated estradiol production in short-term treatments

In order to evaluate the possible role of purinergic agonists on the FSH-stimulated aromatase activity, this enzyme activity was measured in the presence and absence of purinergic agonists. Initial experiments were performed to determine the appropriate doses of CHA and ATP which
Table 1 Effect of CHA and ATP on FSH-stimulated estradiol production. Values are mean \pm S.D. of triplicate incubations in one representative experiment out of three

\begin{tabular}{ll} 
& $\begin{array}{l}\text { Estradiol production } \\
(\mathrm{pg} / \mu \mathrm{g} \mathrm{DNA})\end{array}$ \\
\cline { 2 - 2 } $\begin{array}{l}\text { Treatment } \\
\text { Control }\end{array}$ & $74 \cdot 9 \pm 3 \cdot 6$ \\
$\mathrm{CHA}$ & \\
$1 \mathrm{nM}$ & $67 \cdot 4 \pm 6 \cdot 5$ \\
$10 \mathrm{nM}$ & $54 \cdot 2 \pm 4 \cdot 8^{*}$ \\
$100 \mathrm{nM}$ & $49 \cdot 7 \pm 4 \cdot 5^{*}$ \\
$1000 \mathrm{nM}$ & $52 \cdot 2 \pm 3 \cdot 9^{*}$ \\
ATP & \\
$1 \mu \mathrm{M}$ & $69 \cdot 7 \pm 9 \cdot 0$ \\
$10 \mu \mathrm{M}$ & $60 \cdot 7 \pm 4 \cdot 2^{*}$ \\
$100 \mu \mathrm{M}$ & $53 \cdot 8 \pm 3 \cdot 2^{*}$ \\
$1000 \mu \mathrm{M}$ & $48 \cdot 8 \pm 3 \cdot 2^{*}$
\end{tabular}

Cells were cultured for 5 days in control medium. On the 6 th day cells were stimulated with FSH $(100 \mathrm{ng} / \mathrm{ml})$ and testosterone $(3 \mu \mathrm{M})$ without purinergic agonists (control) or with the addition of variable doses of $\mathrm{CHA}$ or ATP. Twenty-four hours later media were collected and estradiol production determined by RIA.

${ }^{*} P<0 \cdot 05$ vs control.

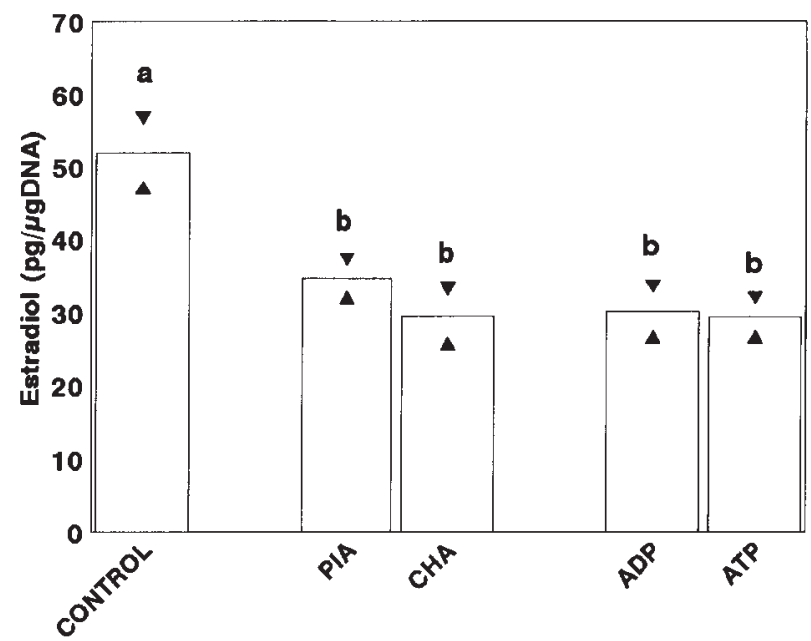

Figure 1 Effect of purinergic agonists on FSH-stimulated estradiol production. Cells were cultured for 5 days in control medium. On the 6th day in culture, cells were stimulated with FSH $(100 \mathrm{ng} / \mathrm{ml})$ and testosterone $(3 \mu \mathrm{M})$ without purinergic agonists (control) or with the addition of PIA (100 nM), CHA (100 nM), ADP $(100 \mu \mathrm{M})$ or ATP $(100 \mu \mathrm{M})$. Twenty-four hours later media were collected and estradiol production determined by RIA. Values are expressed as mean \pm S.D. of triplicate incubations in one representative experiment out of three. Different superscripts indicate statistically significant differences $(P<0 \cdot 05)$.

elicited a response on estradiol production (Table 1). The lowest doses of CHA and ATP which produced a statistically significant inhibition of estradiol production were $10 \mathrm{nM}$ and $10 \mu \mathrm{M}$ respectively. Figure 1 shows that not only $100 \mathrm{nM}$ CHA but also $100 \mathrm{nM}$ PIA (both $\mathrm{A}_{1}$ receptor agonists) inhibited $\mathrm{FSH}$-stimulated estradiol 
Table 2 Effect of purinergic agonists on dbcAMP-stimulated estradiol production. Values are expressed as mean \pm S.D. of triplicate incubations in one representative experiment out of three

\section{Estradiol production

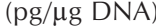

\begin{tabular}{ll}
\cline { 2 - 2 } Treatment & \\
Control & $40 \cdot 9 \pm 1 \cdot 2^{\mathrm{a}}$ \\
PIA & $40 \cdot 4 \pm 3 \cdot 7^{\mathrm{a}}$ \\
CHA & $44 \cdot 2 \pm 0 \cdot 2^{\mathrm{a}}$ \\
ADP & $23 \cdot 5 \pm 0 \cdot 9^{\mathrm{b}}$ \\
ATP & $28 \cdot 0 \pm 4 \cdot 0^{\mathrm{b}}$
\end{tabular}

Cells were cultured for 5 days in control medium. On the 6 th day cells were stimulated with dbcAMP $(0 \cdot 2 \mathrm{mM})$ and testosterone $(3 \mu \mathrm{M})$ without purinergic agonists (control) or with the addition of PIA (100 nM), CHA $(100 \mathrm{nM})$, ADP $(100 \mu \mathrm{M})$, or ATP $(100 \mu \mathrm{M})$. Twenty-four hours later media were collected and estradiol production determined by RIA.

Different superscripts indicate statistically significant differences $(P<0 \cdot 05)$.

production as previously shown by other authors (Monaco et al. 1984). Figure 1 also shows that inhibitory results similar to those obtained with $100 \mu \mathrm{M}$ ATP were obtained with $100 \mu \mathrm{M}$ ADP (both $\mathrm{P}_{2}$ receptor agonists).

Table 2 shows the effect of purinergic agonists on dbcAMP-stimulated aromatase activity. Under these experimental conditions, ADP and ATP inhibited estradiol production while PIA and CHA had no effect.

Effect of purinergic agonists on aromatase activity in long-term treatments

In this set of experiments, stimulation with purinergic agonists was performed for 3 days and the agonists were removed before aromatase activity was determined. Again, initial experiments to determine the appropriate doses of CHA and ATP were performed (Table 3). The lowest doses of CHA and ATP which produced a statistically significant stimulation of aromatase activity were $10 \mathrm{nM}$ and $10 \mu \mathrm{M}$ respectively. Figure 2 shows that under basal conditions prolonged treatment $(72 \mathrm{~h})$ with $100 \mathrm{nM} \mathrm{CHA}$ and PIA, and $100 \mu \mathrm{M} \mathrm{ATP}$ and ADP produced similar stimulatory effects. Figure 2 also shows that prolonged treatment with FSH decreased aromatase activity, while a combination of FSH with purinergic agonists resulted in an aromatase activity which was similar to that obtained in basal control cultures.

Table 4 shows that prolonged treatment with dbcAMP also resulted in inhibition of aromatase activity and that this inhibition was also observed when dbcAMP was combined with CHA. On the other hand, when dbcAMP was combined with ATP, the dbcAMP inhibitory effect was not observed.

\section{Effect of purinergic agonists on $\gamma$-GTP activity}

To study the possible involvement of purinergic agonists in the regulation of basal and FSH-stimulated $\gamma$-GTP
Table 3 Effect of prolonged treatment with $\mathrm{CHA}$ and ATP on aromatase activity. Values are mean \pm S.D. of triplicate incubations in one representative experiment out of three

\section{Estradiol production} $(\mathrm{pg} / \mu \mathrm{g} \mathrm{DNA})$

$\begin{array}{ll}\begin{array}{l}\text { Treatment } \\ \text { Control }\end{array} & 43 \cdot 9 \pm 3 \cdot 6 \\ \text { CHA } & \\ 1 \mathrm{nM} & 44 \cdot 1 \pm 5 \cdot 0 \\ 10 \mathrm{nM} & 64 \cdot 2 \pm 3 \cdot 8^{*} \\ 100 \mathrm{nM} & 75 \cdot 1 \pm 6 \cdot 2^{*} \\ 1000 \mathrm{nM} & 81 \cdot 4 \pm 2 \cdot 3^{*} \\ \text { ATP } & \\ 1 \mu \mathrm{M} & 44 \cdot 1 \pm 5 \cdot 1 \\ 10 \mu \mathrm{M} & 60 \cdot 1 \pm 6 \cdot 8^{*} \\ 100 \mu \mathrm{M} & 74 \cdot 9 \pm 5 \cdot 2^{*} \\ 1000 \mu \mathrm{M} & 62 \cdot 0 \pm 7 \cdot 8^{*} \\ \end{array}$

Cells were maintained for 3 days without additions (control) or with the daily addition of variable doses of CHA or ATP. On the 6th day pretreated monolayers were washed twice and $\mathrm{FSH}(100 \mathrm{ng} / \mathrm{ml})$ and testosterone $(3 \mu \mathrm{M})$ were added. Twenty-four hours later media were collected and estradiol production determined by RIA.

${ }^{*} P<0 \cdot 05$ vs control.

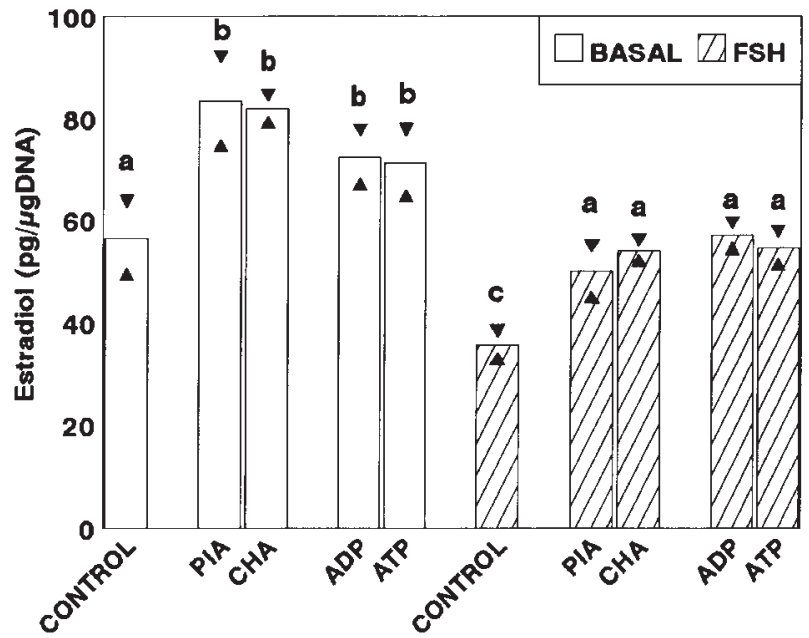

Figure 2 Effect of prolonged treatment with purinergic agonists on basal and FSH-regulated aromatase activity. Cells were maintained for 3 days under basal (open bars) or FSH-stimulated $(100 \mathrm{ng} / \mathrm{ml}$, hatched bars) culture conditions without purinergic agonists (control) or with the daily addition of PIA (100 nM), CHA $(100 \mathrm{nM}), \operatorname{ADP}(100 \mu \mathrm{M})$ or ATP $(100 \mu \mathrm{M})$. On the 6 th day, pretreated monolayers were washed twice and FSH $(100 \mathrm{ng} / \mathrm{ml})$ and testosterone $(3 \mu \mathrm{M})$ were added. Twenty-four hours later media were collected and estradiol production determined by RIA. Values are expressed as mean \pm S.D. of triplicate incubations in one representative experiment out of three. Different superscripts indicate statistically significant differences $(P<0 \cdot 05)$.

activity, we added these agonists to basal and FSHstimulated cultures daily for a 4 day period. Figure 3 shows that prolonged treatment with PIA, CHA, ADP or ATP did not modify basal $\gamma$-GTP activity. On the other hand, 
Table 4 Effect of prolonged treatment with purinergic agonists on dbcAMP-regulated aromatase activity. Values are mean \pm S.D. of triplicate incubations in one representative experiment out of three

\section{Estradiol production}

$(\mathrm{pg} / \mu \mathrm{g} \mathrm{DNA})$

\begin{tabular}{ll}
\cline { 2 - 2 } Treatment & \\
Basal & $53 \cdot 2 \pm 3 \cdot 9^{\mathrm{a}}$ \\
dbcAMP & $34 \cdot 6 \pm 6 \cdot 1^{\mathrm{b}}$ \\
dbcAMP+CHA & $30 \cdot 9 \pm 1 \cdot 9^{\mathrm{b}}$ \\
dbcAMP+ATP & $59 \cdot 1 \pm 2 \cdot 6^{\mathrm{a}}$
\end{tabular}

Cells were maintained for 3 days under basal or dbcAMP-stimulated $(0.2 \mathrm{mM})$ culture conditions with the daily addition of $\mathrm{CHA}(100 \mathrm{mM})$ or ATP $(100 \mu \mathrm{M})$. On the 6 th day pretreated monolayers were washed twice and FSH $(100 \mathrm{ng} / \mathrm{ml})$ and testosterone $(3 \mu \mathrm{M})$ were added. Twenty-four hours later media were collected and estradiol production determined by RIA.

Different superscripts indicate statistically significant differences $(P<0 \cdot 05)$.

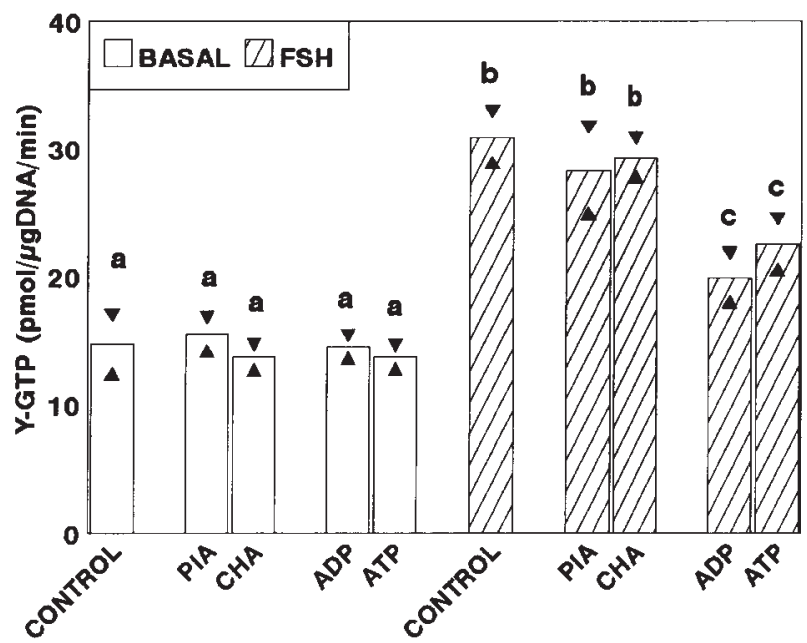

Figure 3 Effect of prolonged treatment with purinergic agonists on basal and FSH-stimulated $\gamma$-GTP activity. Cells were maintained for 4 days under basal (open bars) or FSH-stimulated $(100 \mathrm{ng} / \mathrm{ml}$, hatched bars) culture conditions without purinergic agonists (control) or with the daily addition of PIA $(100 \mathrm{nM}), \mathrm{CHA}$ $(100 \mathrm{nM})$, ADP $(100 \mu \mathrm{M})$ or ATP $(100 \mu \mathrm{M}) . \gamma$-GTP activity was evaluated on the 7 th day. Values are expressed as mean \pm S.D. of triplicate incubations in one representative experiment out of three. Different superscripts indicate statistically significant differences $(P<0 \cdot 05)$.

ADP and ATP inhibited FSH-stimulated $\gamma$-GTP activity while PIA and CHA had no effect.

Table 5 shows that similar results were obtained when the FSH stimulus was replaced by dbcAMP.

\section{Effect of purinergic agonists on transferrin secretion}

Figure 4 shows that treatment with PIA, CHA, ADP or ATP for $72 \mathrm{~h}$ did not modify basal transferrin secretion while all treatments inhibited FSH-stimulated transferrin secretion.
Table 5 Effect of prolonged treatment with purinergic agonists on dbcAMP-regulated $\gamma$-GTP activity. Values are mean \pm S.D. of triplicate incubations in one representative experiment out of three

\section{$\gamma$-GTP activity \\ (pmol/ug DNA/min)}

\begin{tabular}{ll}
\cline { 2 - 2 } Treatment & \\
Basal & $16 \cdot 1 \pm 3 \cdot 0^{\mathrm{a}}$ \\
dbcAMP & $39 \cdot 5 \pm 2 \cdot 7^{\mathrm{b}}$ \\
dbcAMP+CHA & $36 \cdot 6 \pm 3 \cdot 2^{\mathrm{b}}$ \\
dbcAMP+ATP & $29 \cdot 2 \pm 1 \cdot 7^{\mathrm{c}}$
\end{tabular}

Cells were maintained for 4 days under basal or dbcAMP-stimulated $(0 \cdot 2 \mathrm{mM})$ culture conditions with the daily addition of $\mathrm{CHA}(100 \mathrm{nM})$ or ATP $(100 \mu \mathrm{M}) \cdot \gamma$-GTP activity was evaluated on the 7 th day.

Different superscripts indicate statistically significant differences $(P<0 \cdot 05)$.

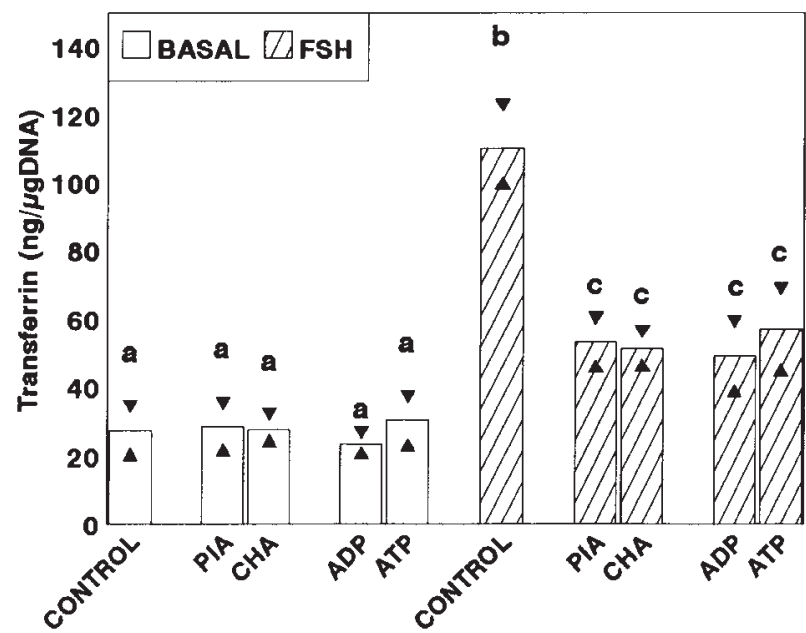

Figure 4 Effect of prolonged treatment with purinergic agonists on basal and FSH-stimulated transferrin secretion. Cells were maintained for 3 days under basal (open bars) or FSH-stimulated $(100 \mathrm{ng} / \mathrm{ml}$, hatched bars) culture conditions without purinergic agonists (control) or with the daily addition of PIA (100 nM), CHA $(100 \mathrm{nM})$, ADP $(100 \mu \mathrm{M})$ or ATP $(100 \mu \mathrm{M})$. The 72 -h accumulated medium was collected and transferrin concentration was determined by RIA. Values are expressed as mean \pm S.D. of triplicate incubations in one representative experiment out of three. Different superscripts indicate statistically significant differences $(P<0 \cdot 05)$.

Table 6 shows that CHA did not modify dbcAMPstimulated transferrin secretion. It also shows that ATP inhibited dbcAMP-stimulated transferrin secretion.

\section{Effects of different treatments on Sertoli cell morphology}

Figure 5A shows Sertoli cells in culture forming a confluent epithelioid monolayer. Figures $5 \mathrm{~B}$ and $\mathrm{C}$ show that no changes in cell morphology were observed in cultures stimulated with CHA and ATP respectively. Figures $5 \mathrm{D}$ and $\mathrm{G}$ show the characteristic morphological changes provoked by FSH and dbcAMP respectively. Co-treatment with CHA reversed the morphological 
Table 6 Effects of prolonged treatments with purinergic agonists on dbcAMP-regulated transferrin secretion. Values are mean \pm S.D. of triplicate incubations in one representative experiment out of three

\begin{tabular}{ll} 
& $\begin{array}{l}\text { Transferrin } \\
(\mathrm{ng} / \mu \mathrm{\mu g} D N A)\end{array}$ \\
\cline { 2 - 2 } $\begin{array}{l}\text { Treatment } \\
\text { Basal }\end{array}$ & $25 \cdot 2 \pm 4 \cdot 2^{\mathrm{a}}$ \\
dbcAMP & $83 \cdot 3 \pm 10 \cdot 2^{\mathrm{b}}$ \\
dbcAMP+CHA & $79 \cdot 8 \pm 1 \cdot 6^{\mathrm{b}}$ \\
dbcAMP+ATP & $58 \cdot 6 \pm 9 \cdot 3^{\mathrm{c}}$
\end{tabular}

Cells were maintained for 3 days under basal or dbcAMP-stimulated $(0 \cdot 2 \mathrm{mM})$ culture conditions with the daily addition of $\mathrm{CHA}(100 \mathrm{nM})$ or ATP $(100 \mu \mathrm{M})$. Transferrin was determined by RIA in the $72-\mathrm{h}$ conditioned medium.

Different superscripts indicate statistically significant differences $(P<0 \cdot 05)$.

changes induced by FSH (Fig. 5E) but did not modify those promoted by dbcAMP (Fig. 5H). Finally, ATP was able to reverse the morphological changes promoted by both FSH (Fig. 5H) and dbcAMP (Fig. 5I). Pictures were taken on the 6th day after a 72-h treatment with FSH, dbcAMP and the different purinergic agonists.

\section{Discussion}

It is now well established that extracellular nucleosides and nucleotides are important regulators of cell function in several tissues (Burnstock 1990). Data reported so far on the regulation of Sertoli cell function were reviewed in the Introduction. In the present study, additional evidence of the potential role of nucleosides and nucleotides in the regulation of Sertoli cell function is presented. This evidence has been obtained by evaluating the effect of purinergic agonists on three well-known Sertoli cell parameters: aromatase and $\gamma$-GTP activities and transferrin secretion.

Sertoli cell aromatase activity is stimulated after a short-term exposure to FSH. This FSH-stimulated aromatase activity decreases markedly throughout pubertal development (Dorrington \& Armstrong 1979). In 10- to 20-day-old Sertoli cell cultures it has also been shown that FSH-stimulated aromatase activity can be regulated by germ cell derived factors (Le Magueresse \& Jégou 1986) and by several growth factors (Mallea et al. 1986, Khan \& Nieschlag 1991, Morera et al. 1992). On the other hand, we have recently shown that prolonged treatment $(96 \mathrm{~h}$ ) with FSH provokes a decrease in the ability of FSH or dbcAMP to stimulate aromatase activity acutely. We have interpreted these results as a reflection of a more differentiated state of the cell promoted by hormonal stimulation (Schteingart et al. 1995).

Monaco et al. (1984) had previously shown that adenosine exerts a regulatory effect on FSH-dependent estradiol production. In agreement with that report, our results show that $A_{1}$ agonists inhibit FSH- but not dbcAMP-stimulated estradiol production in short-term experiments. These results are consistent with the nature of $A_{1}$ receptors in Sertoli cells which are coupled to a $G_{i}$ protein (Monaco et al. 1988). In addition, the results presented herein show that not only $\mathrm{A}_{1}$ agonists but ADP and ATP, which occupy $\mathrm{P}_{2}$ receptors, inhibit estradiol production in short-term experiments.

ADP and ATP are metabolized to AMP and adenosine in reactions catalyzed by an ecto-ATPase and a $5^{\prime}-$ nucleotidase. These enzymes are present at the plasma membrane in different cells (Emmelot \& Bos 1966, Filippini et al. 1990). If ATP and ADP were metabolized, their effects could be related to the action of metabolic products through $A_{1}$ receptors. Yet, two lines of evidence defy this possibility. First, the ecto-ATPase, which has been recently identified in Sertoli cells, is inactive with ADP (Barbacci et al. 1996). Secondly, ADP and ATP also inhibit dbcAMP-stimulated estradiol production while PIA and CHA do not.

It has been recently demonstrated that occupancy of Sertoli cell $\mathrm{P}_{2 \mathrm{U}}$ receptors promotes phosphoinositide turnover with the subsequent elevation of inositol triphosphate and a rapid increase in intracellular $\mathrm{Ca}^{2+}$ accompanied by decreased cAMP response to FSH stimulation (Filippini et al. 1994). This decreased cAMP response could follow a $\mathrm{Ca}^{2+}$-dependent activation of a cyclic nucleotide phosphodiesterase provoked by increased intracellular $\mathrm{Ca}^{2+}$ levels. The activation of protein kinase C (PKC) activity which follows elevations of diacylglycerol upon hydrolysis of phosphatidylinositol can also contribute to the observed phenomenon. The decrease in cAMP provoked by activation of these signal molecules might explain the inhibition of FSH-stimulated estradiol production. However, this possibility is questioned by the results mentioned before, which demonstrate the inability of dbcAMP to overcome the inhibitory effects of ATP. In addition, these results show that ATP effects are produced at a site distal to cAMP production. Our results agree with previous observations demonstrating that PKC activity and intracellular $\mathrm{Ca}^{2+}$ levels are involved in the regulation of aromatase activity at a site distal to cAMP accumulation (Monaco \& Conti 1987, Talbot et al. 1991). ATP regulation of other steroid-producing cells, like granulosa and Leydig cells, has recently been presented (Kamada et al. 1994, Foresta et al. 1996).

The effects produced by occupancy of purinergic receptors described so far in this paper, and those published by other authors, have been obtained in short-term $(24 \mathrm{~h})$ stimulation periods and little is known about the consequences that prolonged treatments may have on Sertoli cell function. We have observed that a 72-h treatment with $\mathrm{A}_{1}$ and $\mathrm{P}_{2}$ agonists under basal conditions results in an increase in aromatase activity. Conti et al. (1989) had previously observed a similar effect in 

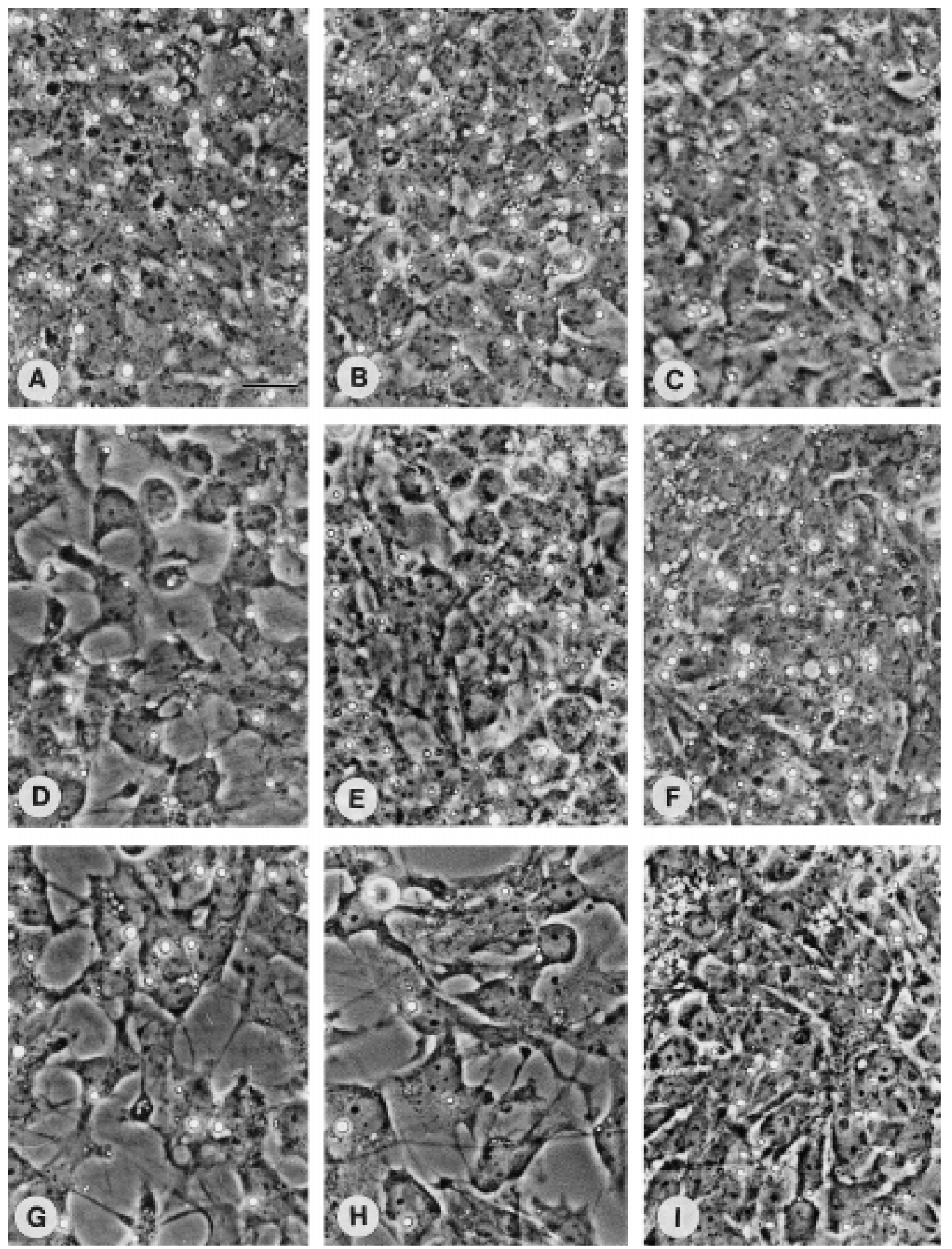

Figure 5 Micrographs of Sertoli cells. (A) control cells; (B) CHA 100 nM; (C) ATP $100 \mu \mathrm{M}$; (D) FSH 100 ng/ml; (E) and (F) combined treatments with $100 \mathrm{ng} / \mathrm{ml} \mathrm{FSH}$ and CHA $100 \mathrm{nM}$ or ATP $100 \mu \mathrm{M}$ respectively; (G) dbcAMP 0.2 mM; $(\mathrm{H})$ and (I) combined treatments with $0 \cdot 2 \mathrm{mM}$ dbcAMP and CHA $100 \mathrm{nM}$ or ATP $100 \mu \mathrm{M}$ respectively. All treatments lasted $72 \mathrm{~h}$. The selected microscopic fields are representative of predominant morphology of the cells in triplicate incubations that were repeated three times. Horizontal bar (in (A)) represents $20 \mu \mathrm{m}$. 
long-term experiments with $A_{1}$ agonists. Those authors considered the fact that long-term activation of a receptor could lead to desensitization. However, they observed that $\mathrm{A}_{1}$ agonists were still able to inhibit cAMP production after long-term experiments and we have observed that purinergic agonists are still able to modulate aromatase activity after long-term treatments. Altogether, these results suggest that the observed effects are not related to desensitization but to other mechanisms which remain to be elucidated. In spite of the molecular mechanisms involved, these results suggest that cell exposure to purinergic agonists for prolonged periods of time promotes a less differentiated state of Sertoli cells. This latter proposal is further sustained by the observations made in FSHstimulated cultures where purinergic agonist treatments have been shown to counteract the differentiating effects of FSH.

As mentioned before, we have also analyzed the effect of purinergic treatments on two other parameters of Sertoli cell function which may also be regarded as markers of Sertoli cell differentiation (Hodgen \& Sherins 1973, Skinner et al. 1989, Chaudhary et al. 1996). $\gamma-G T P$ activity increases with the age of the Sertoli cell donor ( $\mathrm{Lu}$ \& Steinberger 1977, Sanborn et al. 1986) and it has been shown to be stimulated by FSH and by germ cell secreted products (Schteingart et al. 1989). Transferrin can also be stimulated by FSH (Skinner \& Griswold 1980), several growth factors (Skinner \& Griswold 1982) and germ cell derived factors of unknown nature (Le Magueresse et al. 1988). To our knowledge no reports are available on the potential effect that prolonged treatments with purinergic agonists may have on these two parameters of Sertoli cell function. Our results show that under the latter experimental conditions regulation of $\gamma$-GTP activity and transferrin secretion does exist. However, the changes observed were less pronounced than those described for aromatase activity. Neither $\gamma$-GTP activity nor transferrin secretion was modified by purinergic treatments under basal conditions. These results probably reflect the fact that these parameters do not change with cell differentiation as markedly as aromatase activity does. On the other hand, under conditions where cell differentiation is favored by FSH treatment a reduction in $\gamma$-GTP activity and transferrin secretion was usually observed.

Similar signal transduction pathways to those mentioned for the regulation of aromatase activity by $\mathrm{A}_{1}$ and $\mathrm{P}_{2}$ agonists in short-term experiments are probably involved in the observed long-term regulatory effects. In all cases the regulatory effects of ATP, but not those of CHA, were also observed when FSH was replaced by dbcAMP stimulation. Similar observations were made on the morphological changes induced by these agonists. Altogether the results obtained indicate that in addition to the ability of ATP to regulate FSH stimulated cAMP levels, this nucleotide can exert regulatory actions which are produced beyond cAMP formation. As to the results obtained with ATP on $\gamma$-GTP activity, they are in agreement with our recent observations demonstrating that FSHstimulated $\gamma$-GTP activity can be regulated by a PKCdependent pathway at a site distal to cAMP formation (Meroni et al. 1997).

It has been reported that ATP may cause cell membrane permeation and cytolysis in different cells (Filippini et al. 1990). We think that the effects reported here for ATP are due to specific interactions with membrane receptors rather than to nonspecific cytotoxic effects as (1) a well-preserved morphology was observed after a 72-h stimulation period with ATP, and (2) Trypan Blue exclusion tests showed that cell viability was higher than $95 \%$.

In conclusion, these results demonstrate that Sertoli cells can be regulated by purinergic agonists. The source of these purinergic agonists in the extracellular space is still unknown but the possibility that they may represent components of the complex network involved in paracrine/autocrine actions is attractive.

\section{Acknowledgements}

The authors wish to thank the National Institute of Diabetes, Digestive and Kidney Diseases (NIDDK), Bethesda, MD, USA, for the gift of o-FSH. The technical help of Mercedes Astarloa and the photographic assistance of Oscar Rodriguez are gratefully acknowledged. We also wish to thank Celia Nieto for revising the English version of the manuscript. This work was supported by grants from CONICET and FONCYT, Argentina.

\section{References}

Barbacci E, Filippini A, De Cesaris P \& Ziparo E 1996 Identification and characterization of an ecto-ATPase activity in rat Sertoli cells. Biochemical and Biophysical Research Communications 222 273-279.

Barnard E, Burnstock G \& Webb T 1994 G protein-coupled receptors for ATP and other nucleotides: a new receptor family. Trends in Pharmacological Sciences 15 67-70.

Billig H \& Rosberg S 1988 Evidence for $\mathrm{A}_{2}$ adenosine receptormediated effects on adenylate cyclase activity in rat ovarian membranes. Molecular and Cellular Endocrinology 56 205-210.

Burnstock G 1990 Purinergic mechanisms. Annals of the New York Academy of Sciences 603 1-17.

Carruthers A \& Fozard J 1993 Adenosine A 3 receptors: two into one won't go. Trends in Pharmacological Sciences 14 290-291.

Conti M, Culler MD \& Negro-Vilar A 1988 Adenosine receptor dependent modulation of inhibin secretion in cultured immature rat Sertoli cells. Molecular and Cellular Endocrinology 59 255-259.

Conti M, Boitani C, Demanno D, Migliaccio S, Monaco L \& Szymeczek C 1989 Characterization and function of adenosine receptors in the testis. Annals of the New York Academy of Sciences 564 39-47.

Chaudhary J, Whaley PD, Cupp A \& Skinner MK 1996 Transcriptional regulation of Sertoli cell differentiation by follicle-stimulating hormone at the level of the c-fos and transferrin promoter. Biology of Reproduction 54 692-699. 
Dorrington JH \& Armstrong DT 1979 Effects of follicle-stimulating hormone on gonadal functions. Recent Progress in Hormone Research 35 301-342.

Dubyak G 1991 Signal transduction by $\mathrm{P}_{2}$-purinergic receptors for extracellular ATP. American Journal of Respiratory Cell and Molecular Biology 4 295-300.

Emmelot P \& Bos CJ 1966 Studies on plasma membranes III. $\mathrm{Mg}^{2+}$-ATPase, $\left(\mathrm{Na}^{+}-\mathrm{K}^{+}-\mathrm{Mg}^{2+}\right)$-ATPase and $5^{\prime}$-nucleotidase activity of plasma membranes isolated from rat liver. Biochimica et Biophysica Acta 120 369-382.

Escobar ME, Rivarola MA \& Bergadá C 1976 Plasma concentration of estradiol $17 \beta$ in premature thelarche and in different types of sexual precocity. Acta Endocrinologica 81 351-361.

Filippini A, Taffs RE, Agui T \& Sitkovsky MV 1990 Ecto-ATPase activity in cytolytic T-lymphocytes. Journal of Biological Chemistry $265334-340$.

Filippini A, Riccioli A, De Cesaris P, Paniccia R, Teti A, Stefanini M, Conti M \& Ziparo E 1994 Activation of inositol phospholipid turnover and calcium signaling in rat Sertoli cells by $\mathrm{P}_{2}$-purinergic receptors: modulation of FSH responses. Endocrinology 134 1537-1545.

Foresta C, Rossato M, Bordon P \& Di Virgilio F 1995 Extracellular ATP activates different signaling pathways in rat Sertoli cells. Biochemical Journal 311 269-274.

Foresta C, Rossato M, Nogara A, Gottardello F, Bordon P \& Di Virgilio F 1996 Role of $\mathrm{P}_{2}$-purinergic receptors in rat Leydig cell steroidogenesis. Biochemical Journal 320 499-504.

Fradkin JE, Hardin WC \& Wolff J 1982 Adenosine receptor-mediated accumulation of adenosine $3^{\prime}, 5^{\prime}$-monophosphate in guinea pig thyroid tissue. Endocrinology 110 2018-2023.

Handelsman DJ, Spaliviero JA, Kidston E \& Robertson DM 1989 Highly polarized secretion of inhibin by Sertoli cells in vitro. Endocrinology 125 721-729.

Hodgen GD \& Sherins RJ 1973 Enzymes as markers of testicular growth and development in the rat. Endocrinology 93 985-990.

Hopwood AM \& Burnstock G 1987 ATP mediates coronary vasoconstriction via $\mathrm{P}_{2 \mathrm{X}}$-purinoceptors and coronary vasodilatation via $\mathrm{P}_{2 \mathrm{Y}}$-purinoceptors in the isolated perfused rat heart. European Journal of Pharmacology 136 49-54.

Kamada S, Blackmore PF, Oehninger S, Gordon K \& Hodgen GD 1994 Existence of $\mathrm{P}_{2}$-purinoceptors on human and porcine granulosa cells. Journal of Clinical Endocrinology and Metabolism 78 650-656.

Khan SA \& Nieschlag E 1991 Interleukin-1 inhibits follitropininduced aromatase activity in immature rat Sertoli cells in vitro. Molecular and Cellular Endocrinology 75 1-7.

Labarca C \& Paigen K 1980 A simple, rapid and sensitive DNA assay procedure. Analytical Biochemistry 102 344-352.

Le Magueresse B \& Jégou B 1986 Possible involvement of germ cells in the regulation of oestradiol- $17 \beta$ and $\mathrm{ABP}$ secretion by immature rat Sertoli cells (in vitro studies). Biochemical and Biophysical Research Communications 141 861-869.

Le Magueresse B, Pineau C, Guillou F \& Jégou B 1988 Influence of germ cells upon transferrin secretion by rat Sertoli cells in vitro. Journal of Endocrinology 118 13-16.

Londos C \& Wolff J 1977 Two distinct adenosine-sensitive sites on adenylate cyclase. Proceedings of the National Academy of Sciences of the USA 74 5482-5486.

Loubatieres-Mariani MM \& Chapal J 1988 Purinergic receptors involved in the stimulation of insulin and glucagon secretion. Diabete et Metabolisme 14 119-126.

Lu C \& Steinberger A 1977 Gamma-glutamyl transpeptidase activity in the developing rat testis, enzyme localization in isolated cell types. Biology of Reproduction 17 84-88.

Mallea LE, Machado AJ, Navaroli F \& Rommerts FFG 1986 Epidermal growth factor stimulates lactate production and inhibits aromatization in cultured Sertoli cells from immature rats. International Journal of Andrology 9 201-208.
Martin W, Cusack NJ, Carleton JS \& Gordon JL 1985 Specificity of the $\mathrm{P}_{2}$-purinoceptors that mediate endothelium-dependent relaxation of the pig aorta. European Journal of Pharmacology 108 295-299.

Meroni S, Cánepa D, Pellizzari E, Schteingart H \& Cigorraga S 1997 Regulation of $\gamma$-glutamyl transpeptidase activity by $\mathrm{Ca}^{2+}-$ and protein kinase C-dependent pathways in Sertoli cells. International Journal of Andrology 20 189-194.

Monaco L \& Conti M 1986 Localization of adenosine receptors in rat testicular cells. Biology of Reproduction 35 258-266.

Monaco L \& Conti M 1987 Inhibition by phorbol esters and other tumor promoters of the response of the Sertoli cell to FSH: evidence for dual site of action. Molecular and Cellular Endocrinology 49 227-236.

Monaco L, Toscano M \& Conti M 1984 Purine modulation of the hormonal response of the rat Sertoli cell in culture. Endocrinology $1151616-1624$.

Monaco L, Demanno A, Martin M \& Conti M 1988 Adenosine inhibition of the hormonal response in the Sertoli cell is reversed by pertussis toxin. Endocrinology 122 2692-2698.

Morera AM, Esposito G, Ghiglieri C, Chauvin MA, Hartmann DJ \& Benahmed M 1992 Transforming growth factor beta-1 inhibits gonadotropin action in cultured porcine Sertoli cells. Endocrinology 130 831-836.

Orlowsky M \& Meister A $1963 \gamma$-Glutamyl-p-nitroanilide: a new convenient substrate for determination and study of $\mathrm{L}-$ and D- $\gamma$-glutamyltranspeptidase activities. Biochimica et Biophysica Acta 73 679-681.

Paton DM \& Taerum T 1990 A comparison of $\mathrm{P}_{1^{-}}$and $\mathrm{P}_{2^{-}}$ purinoreceptors. Annals of the New York Academy of Sciences $\mathbf{6 0 3}$ 165-171.

Sanborn BM, Wagle JR, Steinberger A \& Greer-Emmert D 1986 Maturational and hormonal influences on Sertoli cell function. Endocrinology 118 1700-1709.

Schteingart HF, Rivarola MA \& Cigorraga SB 1989 Hormonal and paracrine regulation of $\gamma$-glutamyl transpeptidase in rat Sertoli cells. Molecular and Cellular Endocrinology 67 73-80.

Schteingart HF, Meroni SB, Pellizzari EH, Loaiza Perez A \& Cigorraga SB 1995 Regulation of Sertoli cell aromatase activity by cell density and prolonged stimulation with FSH, EGF, insulin and IGF-I at different moments of pubertal development. Journal of Steroid Biochemistry and Molecular Biology 52 375-381.

Shima S 1986 Inhibition by adenosine of ACTH-stimulated adenylate cyclase and steroidogenesis in the adrenal cortex. Molecular and Cellular Endocrinology 47 35-42.

Skinner MK \& Griswold MD 1980 Sertoli cells synthesize and secrete transferrin-like protein. Journal of Biological Chemistry 255 9523-9525.

Skinner MK \& Griswold MD 1982 Secretion of testicular transferrin by cultured Sertoli cells is regulated by hormones and retinoids. Biology of Reproduction 27 211-221.

Skinner MK, Schlitz SM \& Anthony CT 1989 Regulation of Sertoli cell differentiated function: testicular transferrin and androgen-binding protein expression. Endocrinology 124 3015-3024.

Stehle JH, Rivkees SA, Lee JJ, Weaver DR, Deeds JD \& Reppert SM 1992 Molecular cloning and expression of the cDNA for a novel $\mathrm{A}_{2}$-adenosine receptor subtype. Molecular Endocrinology 6 384-393.

Talbot JA, Lambert A, Mitchell R, Grabinski M, Anderson DC, Tsatsoulis A, Shalet SM \& Robertson WR 1991 Follicle-stimulating hormone-dependent estrogen secretion by rat Sertoli cells in vitro: Modulation by calcium. Acta Endocrinologica 125 280-285.

Received 17 September 1997 Accepted 22 December 1997 